Article

\title{
Plasma Exfoliated Graphene: Preparation via Rapid, Mild Thermal Reduction of Graphene Oxide and Application in Lithium Batteries
}

\author{
Zuyun Luo ${ }^{1,2} \oplus$, Yuanyuan $\mathrm{Li}^{1}{ }^{1}$, Fangfang Wang ${ }^{1}$ and Ruoyu Hong ${ }^{1, *}$ \\ 1 College of Chemical Engineering, Fuzhou University, Fuzhou 350116, China; fzu_lzy@163.com (Z.L.); \\ N160427010@fzu.edu.cn (Y.L.); wangff19900625@163.com (F.W.) \\ 2 College of Zhicheng, Fuzhou University, Fuzhou 350002, China \\ * Correspondence: rhong@fzu.edu.cn
}

Received: 25 December 2018; Accepted: 25 February 2019; Published: 28 February 2019

check for updates

\begin{abstract}
A simple, novel approach is proposed for the preparation of plasma-exfoliated graphene (PEGN) by reducing graphene oxide (GO) through a dielectric-barrier discharge (DBD) plasma treatment in a $\mathrm{H}_{2}$ atmosphere. The surface chemistry, microstructures, and crystallinity of the prepared samples were characterized via X-ray photoelectron spectroscopy, transmission electron microscopy, and Raman spectrometry to determine the formation mechanism of the PEGN. The results demonstrated that the prepared PEGN had only a few layers in its structure and that most of the functional groups containing oxygen on the GO surface were removed. The PEGN exhibited a considerably higher capacity, better cycling stability, and favorable electron transfer rate for use as a cathode material for lithium-ion batteries. This proposed approach is fast, convenient, and inexpensive, constituting a novel means of producing graphene.
\end{abstract}

Keywords: graphene oxide; low-temperature plasma; cathode material; lithium battery

\section{Introduction}

Graphene, a flat monolayer of carbon atoms that are packed into 2-D honeycomb lattices, has attracted considerable attention in recent years for its high thermal and electrical conductivity, outstanding mechanical strength, and large specific surface area. Graphene-based materials have the potential for application to several fields, such as energy storage [1,2], transparent electrodes [3], lithium-ion batteries (LIBs) [4-7], solar cells [8], fuel cells [9,10], air separation [11], and building materials [12]. Therefore, there is a need for high-quality, large-scale graphene samples. To date, various methods have been developed for fabricating graphene, such as the exfoliation of highly oriented pyrolytic graphite via mechanical methods [13], sublimating silicon from silicon carbide [14,15], thermal- [16,17] or plasma-strengthened chemical vapor deposition [18], and the thermal exfoliation and reduction of graphene oxide (GO) [19]. Therein, synthesizing large quantities of GO from inexpensive graphite powder is a potential alternative solution for the batch manufacturing of materials based on graphene. Nevertheless, the chemical reduction of GO requires the use of strong chemical reductants, such as hydrazine $\left(\mathrm{N}_{2} \mathrm{H}_{4}\right)[20,21]$ and sodium borohydride $\left(\mathrm{NaBH}_{4}\right)$ [22], both of which are dangerous and environmental pollutants. Alternatively, removing oxygen in an Ar atmosphere, a $\mathrm{H}_{2}$ atmosphere, or an ultrahigh-vacuum environment through thermal annealing has also been proposed [23]; however, the high-temperature requirement restricts the range of application of such substrates. Flash reduction [24] and electrochemical reduction [25] are novel, environmentally friendly, and low-temperature methods of GO reduction. With these methods, plasma discharge can make the effective removal of oxygen-containing functional groups possible during the low-temperature 
generation of high-purity atomic hydrogen [26]. However, there are energetic species (such as ions) in plasmas and these energetic species can sputter or damage the materials of atomically thin layers [27].

Therefore, the development of new reduction techniques involving non-toxic chemicals is necessary for the rapid fabrication of large batches of high-quality graphene. The present study addressed a simple, low-cost, and environmentally friendly approach to the synthesis of plasma-exfoliated graphene (PEGN) by reducing GO with dielectric barrier discharge (DBD) plasma under atmospheric pressure. Cyclic voltammetry (CV) measurements revealed that the PEGN, when applied as an anode material for LIBs, exhibited a significantly high rate capability with excellent cycling stability and a high capacitance.

\section{Materials and Methods}

\subsection{Reagents and Materials}

Natural graphite flakes (approximately 300 mesh) were purchased from Qingdao Risheng Co., Ltd. (Qingdao, China). Analytically pure hydrochloric acid was obtained from Quanzhou Donghai Chemical Reagents Company (Quanzhou, China). Sodium nitrate was provided by Taicang Chemical Reagents Co., Ltd. (Taicang, China). Barium chloride and $30 \% \mathrm{H}_{2} \mathrm{O}_{2}$ aqueous solution were purchased from Shanghai Wokai Biotechnology Co., Ltd. (Shanghai, China). Potassium permanganate and 98\% $\mathrm{H}_{2} \mathrm{SO}_{4}$ were supplied by Shanghai Chemical Reagents Company (Shanghai, China). The $\mathrm{LiFePO}_{4}$ (industrial purity) and N-methyl-2-pyrrolidone (battery level) were supplied by Sinopharm Chemical Reagent Co., Ltd. (Shanghai, China). The carbon black and binder (industrial purity) were obtained from Decatur Battery Technology Co., Ltd. (Shenzhen, China). The lithium foil and electrolyte solution (battery level) came from Dongguan Shanshan Battery Materials Co., Ltd. (Dongguan, China). All the chemicals were used directly without further purification. Ultra-pure water was produced using a Millipore system (Burlington, MA, USA).

\subsection{Preparation of $G O$}

GO was prepared from graphite flakes using a modified Hummers method $[28,29]$. The reaction took place at three temperatures: First, $250 \mathrm{~g}$ of natural graphite powder was added to a $50 \mathrm{~L}$ glass reactor followed by $125 \mathrm{~g}$ of $\mathrm{NaNO}_{3}$ and $5.75 \mathrm{~L}$ of $\mathrm{H}_{2} \mathrm{SO}_{4}$ that were stirred for $15 \mathrm{~min}$ over an ice-water bath. Next, $750 \mathrm{~g}$ of $\mathrm{KMnO}_{4}$ was poured into the mixture in batches. The mixture was allowed to continue to react under vigorous agitation for $2 \mathrm{~h}$. Then, the reaction entered the mesothermal stage. The ice-water bath was removed 5 min later, after which the system was heated to $35^{\circ} \mathrm{C}$ and stirred for $4 \mathrm{~h}$. This led to the start of the high-temperature reaction stage in which $12.5 \mathrm{~L}$ of water was slowly poured into the solution. The reaction was then sustained for an additional $30 \mathrm{~min}$. This was followed by the addition of a $3 \mathrm{wt} \% \mathrm{H}_{2} \mathrm{O}_{2}$ aqueous solution until no further bubbling was observed. Finally, $5 \mathrm{~L}$ of $5 \mathrm{wt} \%$ dilute hydrochloric acid was added. Once the reaction was complete, the system was low speed centrifuge washed twice, until the $\mathrm{pH}$ reached about 3 . The sample was then transferred to a hollow fiber membrane for washing to neutrality. After the trace black residue had been filtered out, the homogeneous suspension was collected. The brownish-yellow GO was obtained after drying the suspension using a spray-drying method.

\subsection{Preparation of the PEGN with DBD Plasma}

Figure 1a is a schematic diagram of the apparatus used for the synthesis of PEGN at ambient pressure. GO powder was placed on a porous plate at the center of a vertical quartz tube in a reducer. Prior to discharge, to purify the air in the tube, inert Ar gas was passed through the fluidized bed for $10 \mathrm{~min}$ at $100 \mathrm{~mL} \mathrm{~min}{ }^{-1}$. Then, the DBD plasmas were initiated with an AC input voltage of $50 \mathrm{~V}$ and a current of $1.2 \mathrm{~A}$ at ambient laboratory temperature. $\mathrm{H}_{2}$ gas was introduced to the plasma to generate hydrogen plasma. The stripped product was then separated using a cyclone separator, ultimately 
producing black PEGN powder. The significant expansion of the GO powder in the discharge process at different times is shown in Figure 1b. Figure 1c shows the discharge process.

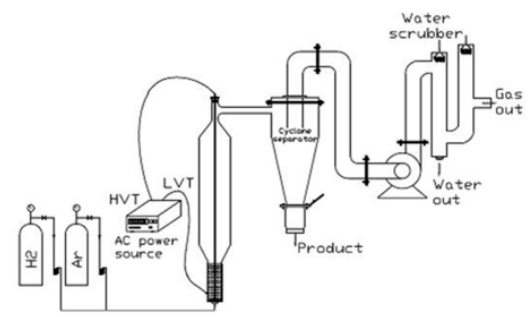

(a)

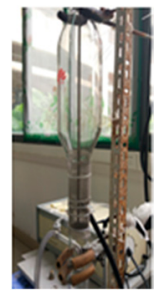

$0 \mathrm{~s}$

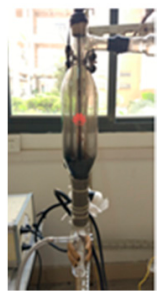

$60 \mathrm{~s}$

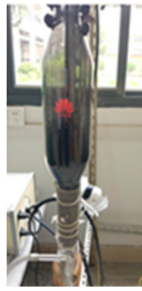

$120 \mathrm{~s}$

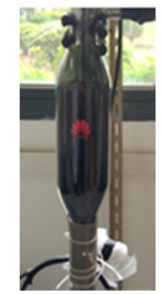

$180 \mathrm{~s}$

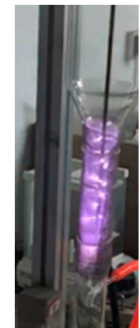

(c)

Figure 1. (a) Schematic representation of the apparatus used to reduce graphene oxide (GO). Low voltage terminal (LVT) and high voltage terminal (HVT) are connected to the low- and high-voltage terminals, respectively; (b) expansion of GO powders after treatment with dielectric-barrier discharge (DBD) plasma for $0,60,120$, and $180 \mathrm{~s}$, respectively; (c) discharge process.

\subsection{Characterization of PEGN}

A Hitachi S-4800 scanning-electron microscope (SEM, Tokyo, Japan) and Hitachi H-600-II transmission electron microscope (TEM) were used to characterize the morphology of the PEGN nanostructures. The critical structures in the PEGN particles were recorded using a Siemens D8 Advance X-ray diffractometer (XRD, Munich, Germany) with Cu-Ka radiation $(=0.15418 \mathrm{~nm}$ ) over a range of $5^{\circ} \leq 2^{\circ} \leq 80^{\circ}$. The Raman analysis was carried out using a Via-Reflex Raman microspectrometer (Renishaw, Wotton-under-Edge, UK) using a continuous-wave laser with a wavelength of $532 \mathrm{~nm}$. Under carbon-hybridized conditions, surface chemical statements were recorded using an X-ray photoelectron spectroscope (XPS, Escallab 250, Thermo Scientific, Waltham, MA, USA) with an Al-K $\alpha$ line and a VG CLAMP hemispherical analyzer (Waltham, MA, USA).

\subsection{Electrochemical Measurement of PEGN}

The prepared PEGN was used to fabricate a coin-type half-cell. This was used as a cathode conductive additive for a LIB with which the electrochemical performance of the PEGN was evaluated. Working electrodes were produced through the mixing of $\mathrm{LiFePO}_{4}, \mathrm{PEGN}$, carbon black (CB), and a poly(vinylidene fluoride) binder that was dispersed in a N-methyl-2-pyrrolidone solution. When $10 \mathrm{wt} \% \mathrm{CB}$ was used as a conductive additive, the amount of binder was $10 \mathrm{wt} \%$. When using PEGN $3 \mathrm{wt} \%$ and a composite conductive agent of $2 \mathrm{wt} \%$ PEGN and $1 \mathrm{wt} \% \mathrm{CB}$, the binder was added in an amount of $3 \mathrm{wt} \%$. Before assembling the coin cells, we spread a prepared slurry containing the active materials uniformly onto the aluminum foil and then dried it in a vacuum oven for $12 \mathrm{~h}$ at $110{ }^{\circ} \mathrm{C}$. LIR2025-type coin cells, assembled in a Lab2000 dry glove box filled with argon (Etelux, Beijing, China), were employed in the subsequent electrochemical experiments. In addition, $\mathrm{LiFePO}_{4} @ \mathrm{PEGN} / \mathrm{CB}$ or $\mathrm{LiFePO}_{4} @ \mathrm{CB}$, pure lithium foil, polypropylene membrane film, and $1 \mathrm{M} \mathrm{LiPF}_{6}$ in ethylene carbon (EC)-dimethyl carbonate (DMC) were used as the working electrode, counter and reference electrodes, separator, and electrolyte, respectively. The galvanostatic charge-discharge (GCD) behavior was measured on a Neware GCD system (CHI600E, Shanghai, China). A CHI-760E electrochemical analyzer (Huakeputian technology Co., Ltd, Beijing, China) was used for CV at a scanning rate of $0.1 \mathrm{mV} / \mathrm{s}$ at voltages in a range of 2.6 to $4.3 \mathrm{~V}\left(\mathrm{v}\right.$. $\left.\mathrm{Li}^{+} / \mathrm{Li}\right)$. The $\mathrm{CHI}-760 \mathrm{E}$ was used for electrochemical impedance spectroscopy (EIS). All electrochemical measurements were carried out at ambient laboratory temperatures. 


\section{Results and Discussion}

\subsection{Characterization Studies}

The schematic representation of the exfoliation and reduction of GO by DBD plasma technology is shown in Figure 2a. During the treatment, the plasma enabled burst open, high-energy collisions between the electrons and ions which were used for exfoliation. During DBD plasma treatment, $\mathrm{H}_{2} \mathrm{O}$ and $\mathrm{CO}_{2}$ gases were discharged abruptly to exfoliate the $\mathrm{GO}$ to a thickness of several few-layers. As shown in Figure 2a, $200 \mathrm{mg}$ of GO only covered a small area of a watch glass. However, after treating the GO with $\mathrm{H}_{2}$ DBD plasma for $3 \mathrm{~min}$, the majority of the surface of the watch glass was covered with the reaction product. This volumetric expansion indicated that the layers of the GO were efficiently and significantly exfoliated. Then, the samples were characterized using SEM, TEM, and atomic force microscopy (AFM, Agilent 5500, NYSE:A, PaloAlto, Santa Clara, CA, USA) to ascertain the structure and thickness of the products. The SEM images in Figure 2c show that thin sheets were produced through the use of the $\mathrm{H}_{2}$ plasma compare with $\mathrm{GO}$ as show in Figure $2 \mathrm{~b}$. A typical TEM image (Figure 2d) shows that there are some wrinkled or folded regions on the planes of the sheet structures. This was probably a consequence of the minimal thickness of the sheets. The presence of the folded structures at the edges of the PEGN, as seen in the HRTEM image (Figure 2e), indicates that most of the PEGN is few-layer. The corresponding selected area electron diffraction (SAED) is shown in Figure 2f. The SAED pattern was represented by weak diffraction rings and diffraction spots, which indicated the loss of the long-range ordering in the graphene layers and the well crystallized few-layer graphene structure [30-32]. Figure $2 \mathrm{~g}$ is a morphology map of graphene as captured by AFM. The corresponding thickness information is shown in Figure $2 \mathrm{~h}$. The thickness of the graphene was about $0.4-0.5 \mathrm{~nm}$, which was slightly greater than the theoretical thickness of single-layer graphene $(0.34 \mathrm{~nm})$. This difference was caused by the uneven surface of the graphene and the presence of a mica sheet at the base. We concluded that, by applying a low-temperature $\mathrm{H}_{2}$ plasma technique, few-layers PEGN can be fabricated from GO.

Then, we further characterized the GO and PEGN from the $\mathrm{N}_{2}$ adsorption and desorption isotherms (3Flex, MicroMetric Inc., Sarasota, FL, USA) at $77 \mathrm{~K}$. It was observed that the $\mathrm{S}_{\mathrm{BET}}$ value of the PEGN was $475 \mathrm{~m}^{2} / \mathrm{g}$, while that of the GO was $101.5 \mathrm{~m}^{2} / \mathrm{g}$. The larger specific surface area was advantageous to the formation of a conductive network. Figure 3a shows that the isotherms were of type-IV with $\mathrm{H}_{2}$ hysteresis loops at relatively high pressures. This indicated that these materials consist of aggregated sheets in which there are typical mesoporous microstructures, while the pore size was found to be approximately $2.38 \mathrm{~nm}$ (inset, Figure 3a). The Raman spectra of GO, graphite, and PEGN are shown in Figure $3 b$. These three spectra all exhibit a D and $G$ band. The $G$ band of PEGN shifted to $1591 \mathrm{~cm}^{-1}$ while that of GO was at $1598 \mathrm{~cm}^{-1}$, approximating to the value of pristine graphite, which suggests that the GO was reduced through the plasma treatment. The D band for both GO and PEGN overtopped that of pristine graphite, predicting the presence of defects in the sample and the size of the in-plane $\mathrm{sp}^{2}$ domain. The intensity ratio ID/IG of the D and G bands varied from 0.94 to 0.95 , suggesting a slight increase in the average size of the $\mathrm{sp}^{2}$ domain after the plasma-treatment-induced reduction of GO [33]. A high energy second-order 2-D peak of the prepared PEGN appeared at around $2656 \mathrm{~cm}^{-1}$ (Figure $3 \mathrm{~b}$ ). This was in good agreement with the results obtained from the examination of a few layers of graphene, fabricated by micromechanical cleavage [34], and chemically-reduced GO [35].

FT-IR, XPS, and XRD investigations were conducted to explore the structural characteristics and chemical composition of GO, graphite, and the product of the plasma treatment. Figure 4 shows the FT-IR spectra of GO, the products of the plasma treatment after 1, 2, and $3 \mathrm{~min}$, and natural graphite. The characteristic peaks of GO appeared at 1730,1622, 1414, 1228, and $1116 \mathrm{~cm}^{-1}$, corresponding to the stretching oscillation of $\mathrm{C}=\mathrm{O}$, aromatic $\mathrm{C}=\mathrm{C}$, carboxy $\mathrm{C}-\mathrm{O}$, epoxy $\mathrm{C}-\mathrm{O}$, and $\mathrm{C}-\mathrm{O}$, respectively [36]. The peaks of oxygen-containing functional groups gradually decreased in amplitude and finally the peak of carboxy $\mathrm{C}-\mathrm{O}$ at $1414 \mathrm{~cm}^{-1}$ disappeared completely after the plasma treatment. Furthermore, the intensity of the peaks corresponding to aromatic $C=C$ at $1622 \mathrm{~cm}^{-1}$ increased with increasing the 
time of the plasma treatment, primarily because the graphite structure was recovered with the increase of the reduction degree.

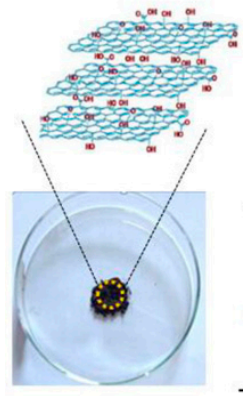

GO

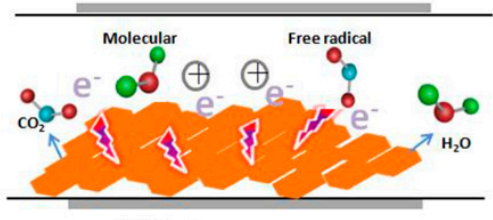

DBD plasma treatment

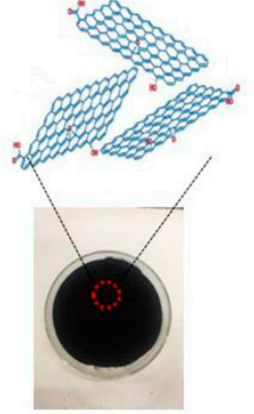

PEGN

(a)

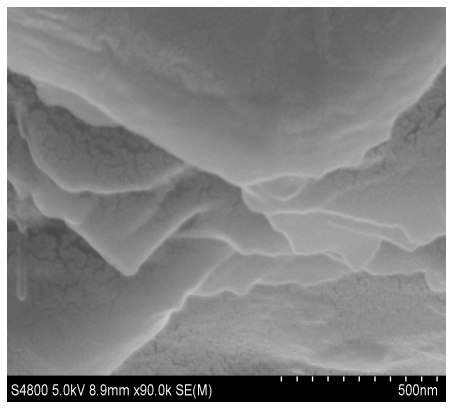

(b)

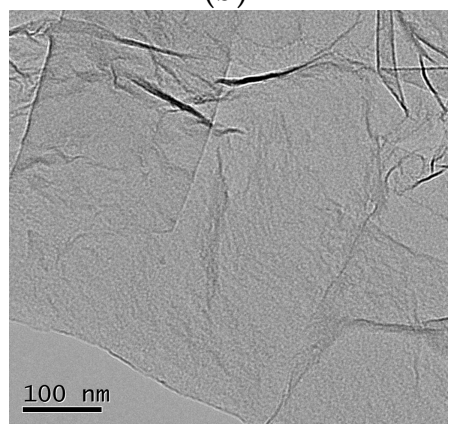

(d)

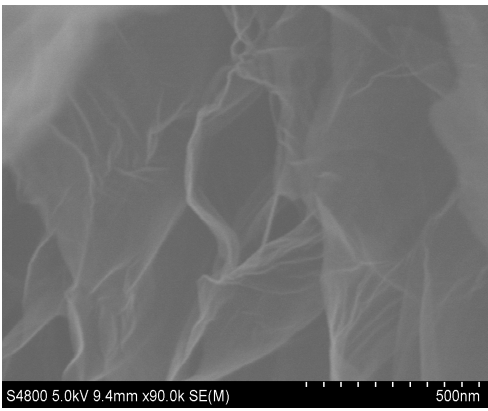

(c)

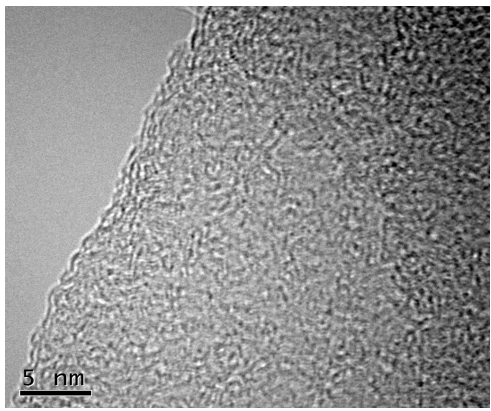

(e)

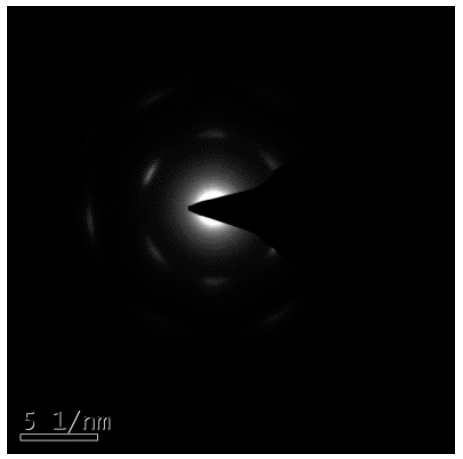

(f)

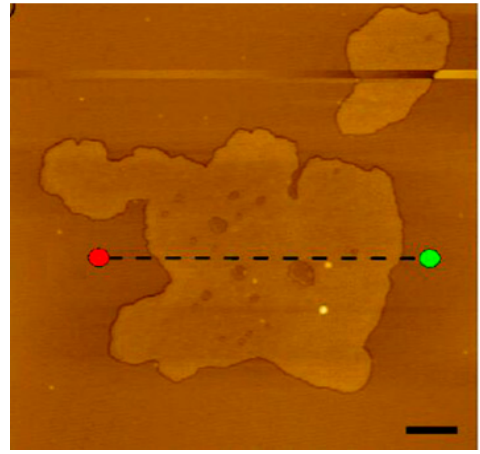

(g)

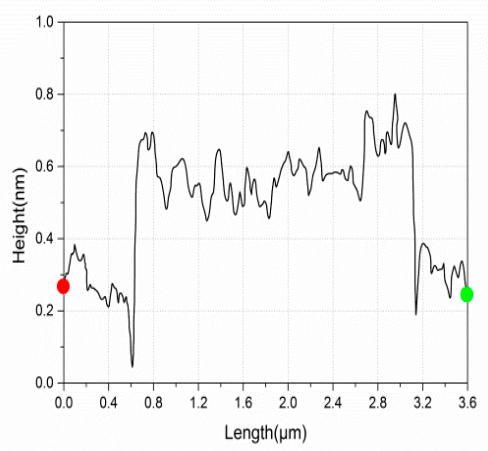

(h)

Figure 2. (a) Schematic representation of exfoliation and reduction of GO using DBD plasma technology; SEM images of (b) GO and (c) plasma-exfoliated graphene (PEGN); (d) TEM and (e) HRTEM images of PEGN; (f) selected area electron diffraction (SAED) pattern indicating a disruption of long-range ordering in graphene; (g) atomic force microscopy (AFM) images of PEGN (scale bar $=500 \mathrm{~nm}$ ). (h) Height profiles along line in (f). 


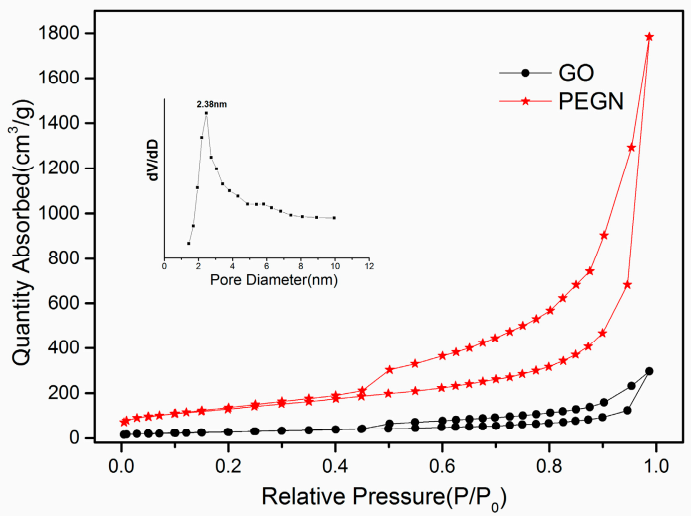

(a)

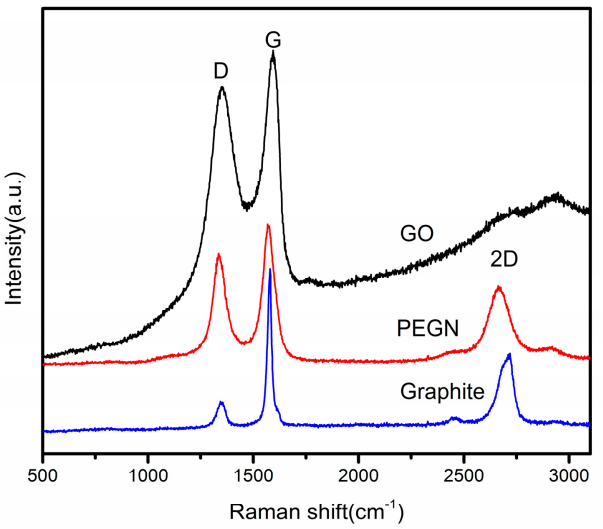

(b)

Figure 3. (a) Nitrogen adsorption and desorption isotherms of PEGN fabricated using $\mathrm{H}_{2}$ DBD plasma at $77 \mathrm{~K}$ (inset: distribution of pore sizes). (b) Raman spectra of graphite, GO, and PEGN.

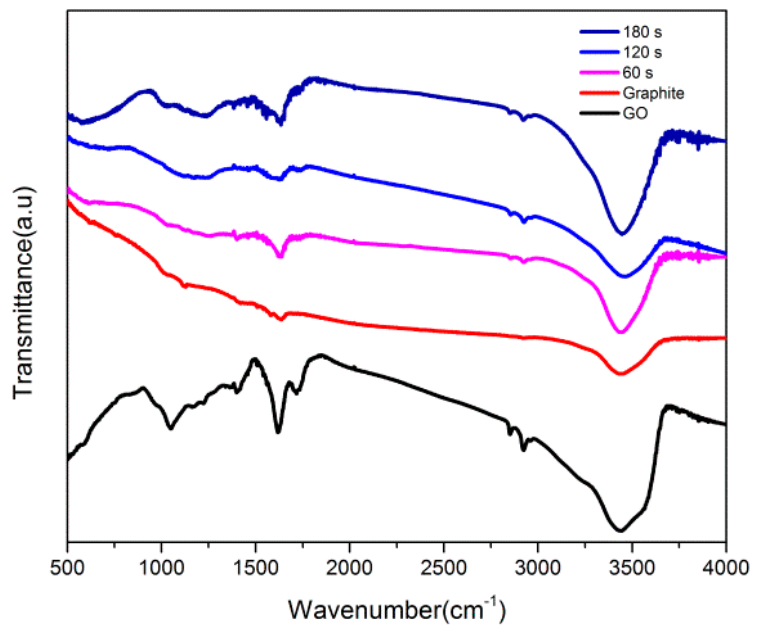

Figure 4. FT-IR spectra of GO, graphite, and the products of plasma treatment for 60,120 , and $180 \mathrm{~s}$, respectively.

Layer spacing is a significant parameter affecting the evaluation of the structural information of graphene. Figure 5 shows the XRD spectra of GO and the products obtained through plasma treatment for different time periods (1,2, and $3 \mathrm{~min}$ ). Compared to natural graphite, GO had a broad peak (about $10^{\circ}$ ), which implied that the regular multilayer crystalline texture of graphite was broken down as a result of oxidation. To investigate the effects of the chosen preparation conditions of PEGN through DBD plasma, we carried out comparative research using different working times. For the product fabricated by plasma-treating GO for 3 and 2 min, no peak was observed, thereby suggesting that the multilayer structure was lost and that single-layer graphene was formed [33].

The results of XPS measurements provided direct evidence for the reduction of GO during plasma treatment. The XPS patterns of GO and the PEGN (obtained via plasma treatment for $3 \mathrm{~min}$ ) are shown in Figure 6. Figure 6a shows the results of a survey scan of the PEGN compared to that of GO. A C 1s peak appears at about $284 \mathrm{eV}$, simultaneously with the $\mathrm{O} 1$ s peak at about $530 \mathrm{eV}$. Figure $6 \mathrm{~b}, \mathrm{c}$ shows the $\mathrm{C} 1 \mathrm{~s}$ high-resolution XPS spectra of GO and PEGN. For GO, the $\mathrm{C} 1 \mathrm{~s}$ spectrum was fitted to the four components at $284.6 \mathrm{eV}(\mathrm{C}-\mathrm{C}), 286.1 \mathrm{eV}(\mathrm{C}-\mathrm{O}), 287.5 \mathrm{eV}(\mathrm{C}=\mathrm{O})$, and $289.2 \mathrm{eV}(\mathrm{O}-\mathrm{C}=\mathrm{O})$; further, the amplitudes of the peaks at $286.1 \mathrm{eV}$ and $287.5 \mathrm{eV}$ decreased after the plasma treatments, and the peak at $289.2 \mathrm{eV}$ disappeared. This is in good agreement with Figure 6a which indicates that the $\mathrm{O} 1 \mathrm{~s}$ peak of GO is lower than that of the PEGN. This indicated that oxygen was removed from the GO to form graphene [23,37]. 


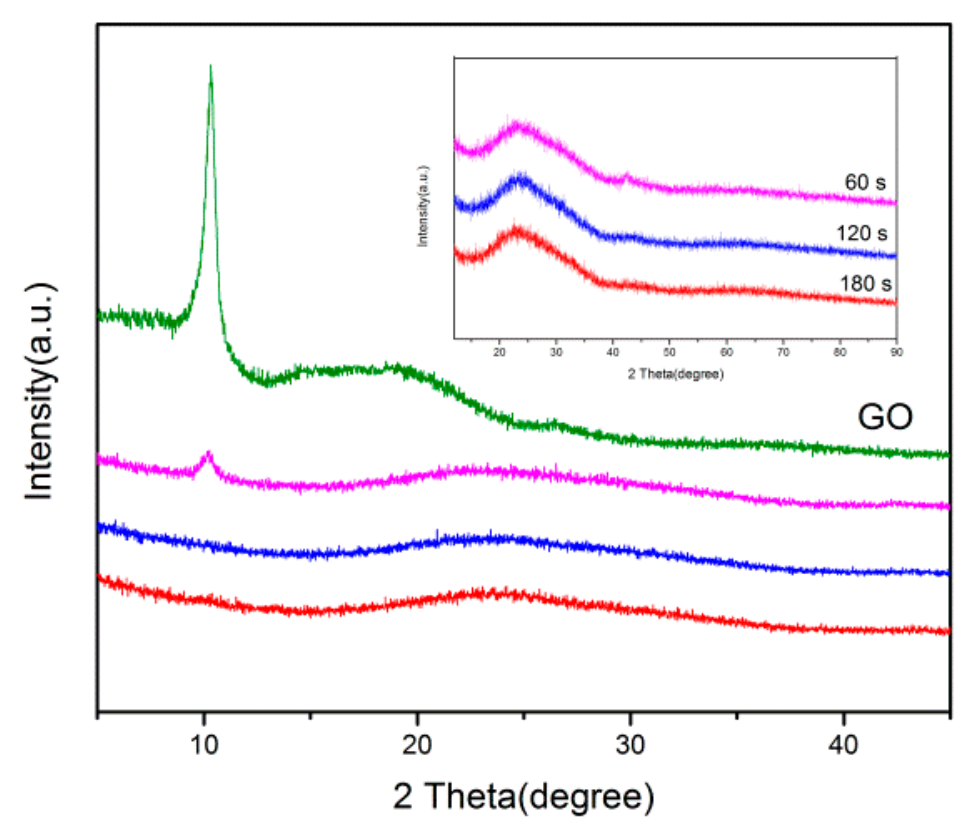

Figure 5. XRD patterns of GO and products of plasma treatment for 1, 2, and $3 \mathrm{~min}$.
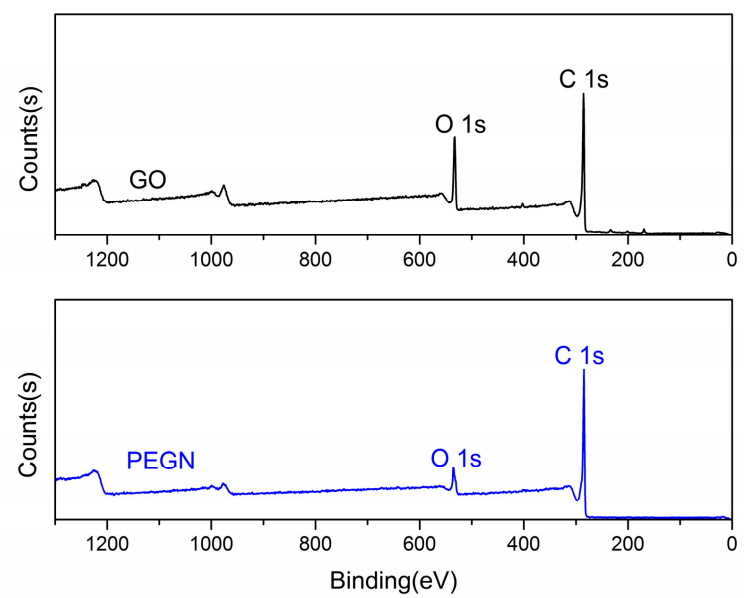

(a)

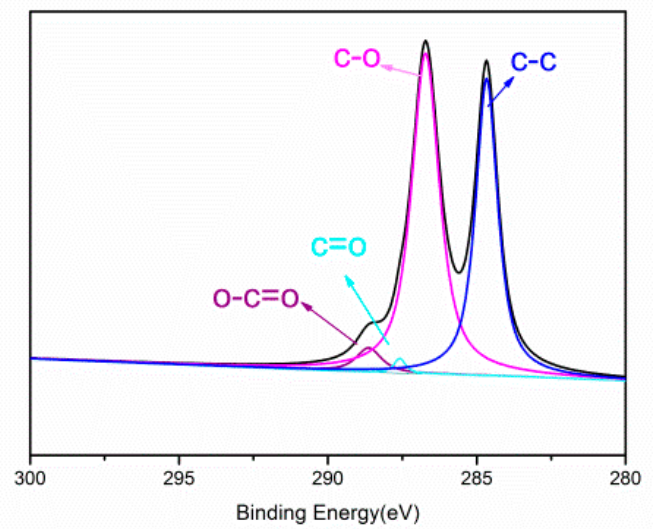

(b)

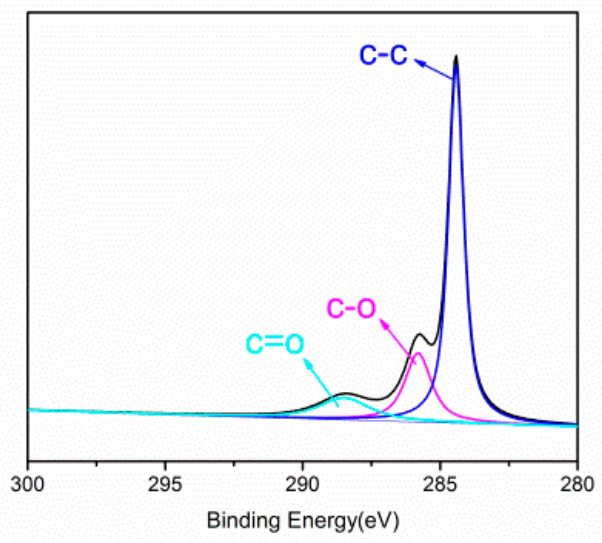

(c)

Figure 6. XPS spectra of GO and PEGN. (a) Survey scan of GO and PEGN. High-resolution C1s spectra of (b) GO and (c) PEGN. 


\subsection{Electrochemical Properties}

To determine whether PEGN could be used to build effective conducting networks for both the ions and electrons that must be transported by the cathode system of LIBs, the electrochemical impedance spectroscopy (EIS), and cyclic voltammetry (CV) measurements were performed on the $\mathrm{LiFePO}_{4} @ \mathrm{CB}$, $\mathrm{LiFePO}_{4} @ \mathrm{PEGN}$, and $\mathrm{LiFePO}_{4} @ \mathrm{PEGN} / \mathrm{CB}$ electrodes before attempting to evaluate their charge/discharge cycle performances. Figure 7a shows the $\mathrm{CV}$ profiles for three different electrodes, scanned at a rate of $0.1 \mathrm{mV} / \mathrm{s}$. As shown in Figure 7a, the redox peaks of the $\mathrm{LiFePO}_{4} @ \mathrm{CB}, \mathrm{LiFePO}_{4} @ \mathrm{PEGN}$, and $\mathrm{LiFePO}_{4} @ \mathrm{PEGN} / \mathrm{CB}$ electrodes are located at 3.270/3.573, 3.278/3.618 and 3.337/3.518 V, respectively. A larger current peak and narrower peak potential separation were found for the $\mathrm{LiFePO}_{4} @ \mathrm{PEGN} / \mathrm{CB}$, while the peak potential difference for $\mathrm{LiFePO}_{4} @ \mathrm{PEGN} / \mathrm{CB}(181 \mathrm{mV})$ was significantly less than that of $\mathrm{LiFePO}_{4} @ \mathrm{PEGN}$ and $\mathrm{LiFePO}_{4} @ \mathrm{CB}(303 \mathrm{mV})$. This suggests that the addition of PEGN made the electrode reaction more reversible and enhanced the kinetic behavior of these electrodes.

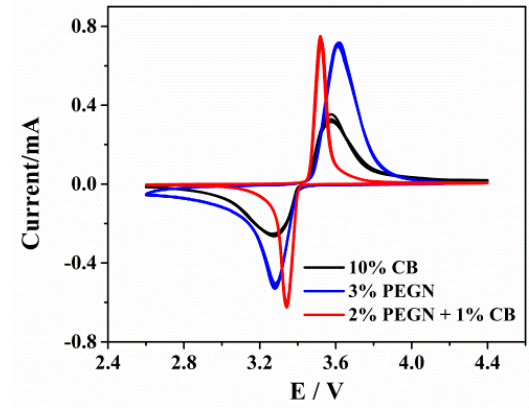

(a)

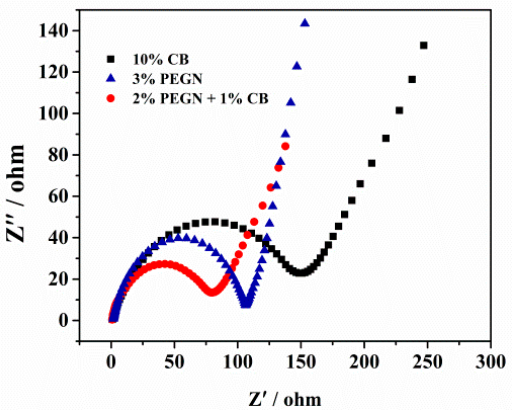

(b)

Figure 7. (a) Cyclic voltammetry (CV) profiles and (b) electrochemical impedance spectroscopy (EIS) patterns for $\mathrm{LiFePO}_{4} @ \mathrm{PEGN} / \mathrm{CB}, \mathrm{LiFePO}_{4} @ \mathrm{PEGN}$, and $\mathrm{LiFePO}_{4} @ \mathrm{CB}$.

Figure $7 \mathrm{~b}$ shows the EIS results for $\mathrm{LiFePO}_{4} @ \mathrm{CB}, \mathrm{LiFePO}{ }_{4} @ \mathrm{PEGN}$, and $\mathrm{LiFePO}_{4} @ \mathrm{PEGN} / \mathrm{CB}$. They are linear and have a depressed semicircular shape in the low- and high-frequency regions of the Nyquist spectra, respectively. The semicircular shape is associated with the resistance to the electrolyte and charge transfer, while the straight line is related to the constant phase element and ion diffusion within the anode. As shown in Figure 7b, the radius of $\mathrm{LiFePO}_{4} @ \mathrm{PEGN} / \mathrm{CB}(79 \Omega)$ was smaller than that of $\mathrm{LiFePO}_{4} @ \mathrm{PEGN}$ $(106 \Omega)$ and $\mathrm{LiFePO}_{4} @ \mathrm{CB}(150 \Omega)$, indicating that as the resistance decreased, the rate of electron transfer and electrical conductivity increased. We can speculate that adding PEGN improved the conductivity, promoted electron transfer, and thus reduced the resistance. Moreover, the plots for $\mathrm{LiFePO}_{4} @ \mathrm{PEGN} / \mathrm{CB}$, $\mathrm{LiFePO}_{4} @ \mathrm{PEGN}$, and $\mathrm{LiFePO}_{4} @ \mathrm{CB}$ have similar shapes, with an arc and an inclined line in the highand low-frequency regions. The former was generally attributed to resistance resulting from the charge transfer between the active material and liquid electrolyte, while the latter appears as $\mathrm{Li}^{+}$diffused into the electrode materials (the so-called Warburg diffusion effect [38]), as a result of ion diffusion. The ions were then transported to the electrode surface depending on the frequency [39].

The electrochemical performances of the three types of $\mathrm{LiFePO}_{4}$ electrodes are compared in Figure 8. Figure 8a shows the curves of the initial charge and discharge of electrodes prepared using $2 \mathrm{wt} \%$ PEGN plus $1 \mathrm{wt} \%$ carbon black, $3 \mathrm{wt} \%$ PEGN or $10 \mathrm{wt} \%$ carbon black additive at a current density of $20 \mathrm{~mA} / \mathrm{g}$. Although the PEGN electrode contained a much lower proportion of additives, the $\mathrm{LiFePO}_{4} @ \mathrm{PEGN} / \mathrm{CB}$ had a higher initial discharge specific capacities of approximately $161 \mathrm{mAh} / \mathrm{g}$ than $\mathrm{LiFePO}_{4} @ \mathrm{PEGN}$ for $156 \mathrm{mAh} / \mathrm{g}$ and $\mathrm{LiFePO}_{4} @ \mathrm{CB}$ for $146 \mathrm{mAh} / \mathrm{g}$, respectively. The capacity of the PEGN electrode was significantly higher than that of an electrode fabricated with a commercial conductive additive. Therefore, we can conclude that a much more effective conductive network can be built in a LIB cathode by adding $2 \mathrm{wt} \%$ PEGN plus $1 \mathrm{wt} \%$ carbon black, thus improving its capacity. Figure $8 \mathbf{b}$ shows the cycling performances of the three types of $\mathrm{LiFePO}_{4}$ electrodes. The discharge specific capacity of $\mathrm{LiFePO}_{4} @ \mathrm{PEGN} / \mathrm{CB}$ remained at $152 \mathrm{mAh} / \mathrm{g}$ even after 100 cycles that 
were in accord with $\mathrm{Su}[40]$. Furthermore, the coulombic efficiencies of the $\mathrm{LiFePO}_{4} @ \mathrm{PEGN} / \mathrm{CB}$, $\mathrm{LiFePO}_{4} @ \mathrm{PEGN}$, and $\mathrm{LiFePO}_{4} @ \mathrm{CB}$ were $94.4 \%, 93.8 \%$, and 90.4\%, respectively, after 100 cycles. These results are a further indication that the addition of PEGN improved the capacity and conductivity. The main reason is that there is a good complementary effect in the contact modes of the graphene and carbon black when using the composite conductive agent. It can establish a more effective "long-range" and "short-range" conductive network inside the electrode [41,42]. This binary conductive agent can improve the dispersion of graphene and prevent the aggregation of graphene, that further improves the efficiency of the electrical conduction [43].

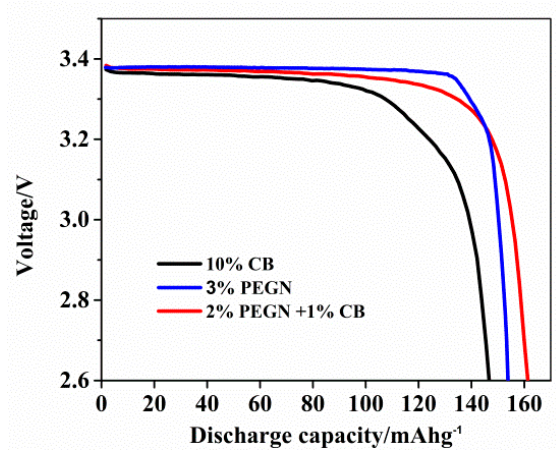

(a)

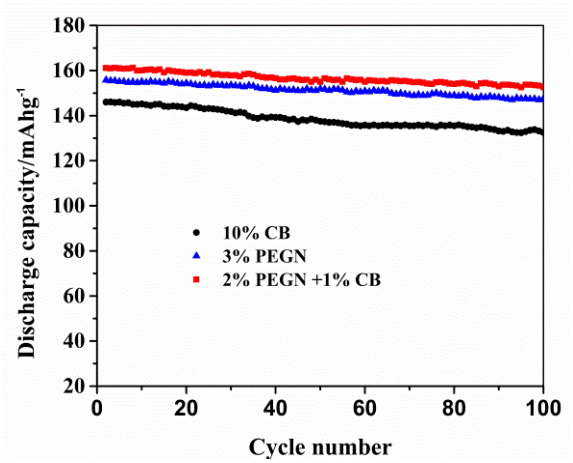

(b)

Figure 8. (a) Discharge curves and (b) cycle performance of $\mathrm{LiFePO}_{4} @ \mathrm{PEGN} / \mathrm{CB}, \mathrm{LiFePO} @ \mathrm{PEGN}$ and $\mathrm{LiFePO}_{4} @ \mathrm{CB}$.

\section{Conclusions}

We propose a simple approach for the preparation of graphene by exfoliating and reducing $\mathrm{GO}$ with DBD plasma in an $\mathrm{H}_{2}$ atmosphere. As a result, most of the functional groups containing oxygen were removed from the surface of the GO. The resulting graphene exhibited a much higher capacity, as well as superior cycling stability and rate performance, compared to carbon black when used as the cathode material in an LIB. This approach offers a simple, environmentally friendly, and cost-effective approach that can be easily applied to the mass production of graphene materials under moderate conditions.

Author Contributions: Conceptualization, Z.L.; data curation, Y.L.; formal analysis, Z.L. and F.W.; funding acquisition, R.H.; investigation, Z.L. and Y.L.; writing一original draft, Z.L. and F.W.; writing一review and editing, Z.L., F.W. and R.H.

Funding: This work was supported by the Natural Science Foundation of China, grant number 21246002, Local R\&D Fund guided by Central Government, grant number 83017078, Natural Science Foundation of Fujian Province, grant number 2018J01431, Fuzhou University Expensive Equipment Open Test Fund Project, grant number 2018T023, Minjiang Scholarship of Fujian Province, Fujian Provincial Department Of Education Youth Project, grant number JT180808, Curriculum Reform Project of College of Zhicheng, Fuzhou University, grant number ZJ1835.

Conflicts of Interest: The authors declare no conflict of interest.

\section{References}

1. Li, L.; Gao, P.; Gai, S.L.; He, F.; Chen, Y.J.; Zhang, M.L.; Yang, P.P. Ultra small and highly dispersed $\mathrm{Fe}_{3} \mathrm{O}_{4}$ nanoparticles anchored on reduced graphene for supercapacitor application. J. Electrochim. Acta 2016, 190, 566-573. [CrossRef]

2. Taluja, Y.; Santhibhushan, B.; Yadav, S.; Srivastava, A. Defect and functionalized graphene for supercapacitor electrodes. Superlattices Microst. 2016, 98, 306-315. [CrossRef]

3. Bae, S.; Kim, H.; Lee, Y.; Xu, X.F.; Park, J.S.; Zheng, Y.; Balakrishnan, J.; Lei, T.; Kim, H.R.; Song, Y.; et al. Roll-to-roll production of 30-inch grapheme films for transparent electrodes. Nat. Nanotechnol. 2010, 5, 574-578. [CrossRef] [PubMed] 
4. Yang, J.; Tian, H.Y.; Tang, J.J.; Bai, T.; Xi, L.H.; Chen, S.M.; Zhou, X.Y. Self-assembled $\mathrm{NiCo}_{2} \mathrm{O}_{4}$-anchored reduced graphene oxide nanoplates as high performance anode materials for lithium ion batteries. Appl. Surf. Sci. 2017, 426, 1055-1062. [CrossRef]

5. Hu, Y.; He, D.W.; Wang, Y.S.; Fu, M.; An, X.F.; Zhao, X. Defect-introduced graphene sheets with hole structure as lithium-ion battery anode. Mater. Lett. 2016, 164, 278-281. [CrossRef]

6. Liu, L.J.; Huang, X.K.; Guo, X.R.; Mao, S.; Chen, J.H. Decorating in situ ultrasmall tin particles on crumpled $\mathrm{N}$-doped graphene for lithium-ion batteries with a long life cycle. J. Power Sources 2016, 328, 482-491. [CrossRef]

7. Jiao, J.Q.; Qiu, W.D.; Tang, J.G.; Chen, L.P.; Jing, L.Y. Synthesis of well-defined $\mathrm{Fe}_{3} \mathrm{O}_{4}$ nanorods/N-doped graphene for lithium-ion batteries. Nano Res. 2016, 9, 1256-1266. [CrossRef]

8. Arefinia, Z.; Asgari, A. An analytical model for optimizing the performance of graphene based silicon Schottky barrier solar cells. Mater. Sci. Semicond. Proc. 2015, 35, 181-188. [CrossRef]

9. Iwan, A.; Caballero-Briones, F.; Malinowski, M.; Filapek, M.; Tazbir, I.; Guerrerocontreras, J.; Kamara, S.K. Graphene oxide influence on selected properties of polymer fuel cells based on Nafion. Int. J. Hydrog. Energy 2017, 42, 15359-15369. [CrossRef]

10. Jee, Y.; Karimaghaloo, A.; Macedo Andrade, A.; Moon, H.; Li, Y.; Han, J.W.; Ji, S.; Ishihara, H.; Su, P.C.; Cha, S.W.; et al. Graphene-based oxygen reduction electrodes for low temperature solid oxide fuel cells. Fuel Cells 2017, 3, 344-352. [CrossRef]

11. Vallejosburgos, F.; Coudert, F.X.; Kaneko, K. Air separation with graphene mediated by nanowindow-rim concerted motion. Nat. Commun. 2018, 9, 130-135.

12. Dimov, D.; Amit, I.; Gorrie, O.; Barnes, M.D.; Townsend, N.J.; Neves, I.S.; Withers, F.; Russo, S.; Craciun, M.F. Ultrahigh performance nanoengineered graphene concrete composites for multifunctional applications. Adv. Funct. Mater. 2018, 28. [CrossRef]

13. Novoselov, K.S.; Geim, A.K.; Morozov, S.V.; Jiang, D.; Zhang, Y.; Dubonos, S.V.; Grigorieva, I.V.; Firsov, A.A. Electric field effect in atomically thin carbon films. Science 2004, 306, 666-669. [CrossRef] [PubMed]

14. Berger, C.; Song, Z.; Li, X.; Wu, X.; Brown, N.; Naud, C.; Mayou, D.; Li, T.; Hass, J.; Marchenkov, A.N.; et al. Electronic confinement and coherence in patterned epitaxial grapheme. Science 2006, 312, 1191-1196. [CrossRef] [PubMed]

15. Emtsev, K.V.; Bostwick, A.; Horn, K.; Jobst, J.; Kellogg, G.L.; Ley, L.; McChesney, J.L.; Ohta, T.; Reshanov, S.A.; Röhrl, J.; et al. Towards wafer-size graphene layers by atmospheric pressure graphitization of silicon carbide. Nat. Mater. 2009, 8, 203-207. [CrossRef] [PubMed]

16. Kim, K.S.; Zhao, Y.; Jang, H.; Lee, S.Y.; Kim, J.M.; Kim, K.S.; Ahn, J.H.; Kim, P.; Choi, J.Y.; Hong, B.H. Large-scale pattern growth of graphene films for stretchable transparent electrodes. Nature 2009, 457, 706-710. [CrossRef] [PubMed]

17. Li, X.; Cai, W.; An, J.; Kim, S.; Nah, J.; Yang, D.; Piner, R.; Velamakanni, A.; Jung, I.; Tutuc, E.; et al. Large-area synthesis of high-quality and uniform graphene films on copper foils. Science 2009, 324, 1312-1314. [CrossRef] [PubMed]

18. Dato, A.; Radmilovic, V.; Lee, Z.; Phillips, J.; Frenklach, M. Substrate-free gas-phase synthesis of graphene sheets. Nano Lett. 2008, 8, 2012-2016. [CrossRef] [PubMed]

19. Schniepp, H.C.; Li, J.L.; McAllister, M.J.; Sai, H.; Herrera-Alonso, M.; Adamson, D.H.; Prud'homme, R.K.; Car, R.; Saville, D.A.; Aksay, I.A. Functionalized single graphene sheets derived from splitting graphite oxide. J. Phys. Chem. B 2006, 110, 8535-8539. [CrossRef] [PubMed]

20. Jung, I.; Dikin, D.; Park, S.; Cai, W.W.; Mielke, L.S.; Ruoff, R.S. Characterization of thermally reduced graphene oxide by Imaging ellipsometry. J. Phys. Chem. C 2008, 112, 20264-20268. [CrossRef]

21. Gilje, S.; Han, S.; Wang, M.; Wang, K.L.; Kaner, R.B. A chemical route to graphene for device applications. Nano Lett. 2007, 7, 3394-3398. [CrossRef] [PubMed]

22. Shin, H.J.; Kim, K.K.; Benayad, A.; Yoon, S.M.; Park, H.K.; Jung, I.S.; Jin, M.H.; Jeong, H.K.; Kim, J.M.; Choi, J.Y.; et al. Efficient reduction of graphite oxide by sodium borohydride and its effect on electrical conductance. Adv. Funct. Mater. 2009, 19, 1987-1992. [CrossRef]

23. Yang, D.; Velamakanni, A.; Bozoklub, G.; Park, S.; Stoller, M.; Piner, R.D.; Stankovich, S.; Jung, I.; Field, D.A.; Ventrice, C.A.; et al. Chemical analysis of graphene oxide films after heat and chemical treatments by $\mathrm{X}$-ray photoelectron and Micro-Raman spectroscopy. Carbon 2009, 47, 145-152. [CrossRef] 
24. Cote, L.J.; Cruzsilva, R.; Huang, J. Flash reduction and patterning of graphite oxide and its polymer composite. J. Am. Chem. Soc. 2009, 131, 11027-11032. [CrossRef] [PubMed]

25. Guo, H.L.; Wang, X.F.; Qian, Q.Y.; Wang, F.B.; Xia, X.H. A green approach to the synthesis of graphene nanosheets. ACS Nano 2009, 3, 2653-2659. [CrossRef] [PubMed]

26. Baraket, M.; Walton, S.G.; Wei, Z.; Lock, E.H.; Robinson, J.T.; Sheehan, P. Reduction of graphene oxide by electron beam generated plasmas produced in methane/argon mixtures. Carbon 2010, 48, 3382-3390. [CrossRef]

27. Teweldebrhan, D.; Balandin, A.A. Modification of graphene properties due to electron-beam irradiation. Appl. Phys. Lett. 2009, 94, 666. [CrossRef]

28. Kovtyukhova, N.I.; Ollivier, P.J.; Martin, B.R.; Mallouk, T.E.; Chizhik, S.A.; Buzaneva, E.V.; Gorchinskiy, A.D. Layer-by-layer assembly of ultrathin composite films from micron-sized graphite oxide sheets and polycations. Chem. Mater. 1999, 11, 771-778. [CrossRef]

29. Stankovich, S.; Dikin, D.A.; Dommett, G.H.B.; Kohlhaas, K.M.; Zimney, E.J.; Stach, E.A.; Piner, R.D.; Nguyen, S.T.; Ruoff, R.S. Graphene-based composite materials. Nature 2006, 442, 282-288. [CrossRef] [PubMed]

30. Zong, J.; Diao, Y.Q.; Ding, F.; Feng, W.; Liu, X.J. Simple method for synthesizing few-layer graphene as cathodes in surface-enabled lithium ion-exchanging cells. Ionics 2016, 22, 1575-1584. [CrossRef]

31. Shen, B.; Lu, D.D.; Zhai, W.T.; Zheng, W.G. Synthesis of graphene by low-temperature exfoliation and reduction of graphite oxide under ambient atmosphere. Mater. Chem. C 2013, 1, 50-53. [CrossRef]

32. Meyer, J.C.; Geim, A.K.; Katsnelson, M.I.; Novoselov, K.S.; Booth, T.J.; Roth, S. The structure of suspended graphene sheets. Nature 2007, 446, 60-63. [CrossRef] [PubMed]

33. Chen, W.F.; Yan, L.F.; Bangal, P.R. Preparation of graphene by the rapid and mild thermal reduction of graphene oxide induced by microwaves. Carbon 2010, 48, 1146-1152. [CrossRef]

34. Ferrari, A.C.; Meyer, J.C.; Scardaci, V.; Casiraghi, C.; Lazzeri, M.; Mauri, F.; Piscanec, S.; Jiang, D.; Novoselov, K.S.; Roth, S.; et al. Raman spectrum of graphene and graphene layers. Phys. Rev. Lett. 2006, 97. [CrossRef] [PubMed]

35. Eda, G.; Fanchini, G.; Chhowalla, M. Large-area ultrathin films of reduced graphene oxide as a transparent and flexible electronic material. Nat. Nanotechnol. 2008, 3, 270-274. [CrossRef] [PubMed]

36. Park, S.; An, J.; Piner, R.D.; Jung, I.; Yang, D.X.; Velamakanni, A.; Nguyen, S.T.; Ruoff, R.S. Aqueous suspension and characterization of chemically modified graphene sheets. Chem. Mater. 2008, 20, 6592-6594. [CrossRef]

37. Fan, X.B.; Peng, W.C.; Li, Y.; Li, X.Y.; Wang, S.L.; Zhang, G.L.; Zhang, F.B. Deoxygenation of exfoliated graphite oxide under alkaline conditions: A green route to graphene preparation. Adv. Mater. 2008, 20, 4490-4493. [CrossRef]

38. Kim, H.J.; Jeong, H.K. Direct reform of graphite oxide electrodes by using ambient plasma for supercapacitor applications. Chem. Phys. Lett. 2017, 686, 49-54. [CrossRef]

39. Yu, H.; Shang, L.; Bian, T.; Shi, R.; Waterhouse, G.I.N.; Zhao, Y.; Zhou, C.; Wu, L.Z.; Tung, C.H.; Zhang, T. Nitrogen-doped porous carbon nanosheets templated from $g-\mathrm{C}_{3} \mathrm{~N}_{4}$ as metal-free electrocatalysts for efficient oxygen reduction reaction. Adv. Mater. 2016, 28, 5080-5086. [CrossRef] [PubMed]

40. Su, C.; Bu, X.D.; Xu, L.H.; Liu, J.L.; Zhang, C. A novel $\mathrm{LiFePO}_{4} /$ graphene/carbon composite as a performance-improved cathode material for lithium-ion batteries. Electrochim. Acta 2012, 64, 190-195. [CrossRef]

41. Badot, J.C.; Ligneel, É.; Dubrunfaut, O.; Guyomard, D.; Lestriez, B. A multiscale description of the electronic transport within the hierarchical architecture of a composite electrode for lithium batteries. Adv. Funct. Mater. 2009, 19, 2749-2758. [CrossRef]

42. Chen, Y.H.; Wang, C.W.; Liu, G.; Song, X.Y.; Battaglia, V.S.; Sastry, A.M. Selection of conductive additives in Li-ion battery cathodes-A numerical study. J. Electrochem. Soc. 2007, 154, A978-A986. [CrossRef]

43. Li, Y.; Lu, X.H.; Su, F.Y. A graphene/carbon black hybrid material: A novel binary conductive additive for lithium-ion batteries. New Carbon Mater. 2015, 30, 128-132. [CrossRef]

(C) 2019 by the authors. Licensee MDPI, Basel, Switzerland. This article is an open access article distributed under the terms and conditions of the Creative Commons Attribution (CC BY) license (http:/ / creativecommons.org/licenses/by/4.0/). 